\title{
Incarceration of indigenous people in Brazil and resolution no. 287 of the National Council of Justice of Brazil
}

\author{
Ela Wiecko Volkmer de Castilho' \\ Tédney Moreira da Silva' \\ 'Universidade de Brasília, Faculdade de Direito, Brasília/Distrito Federal, Brasil
}

\begin{abstract}
This article aims at analyzing Resolution No. 287 of the National Council of Justice of Brazil (CNJ), which establishes special procedures for the treatment of indigenous people who stand as accused, defendants, who are sentenced or are deprived of liberty and shows the necessary process to ensure their rights within the Brazilian Judiciary Branch. It encourages a reflection about why said Resolution's impact on social representations within the Brazilian Judiciary Branch is nearly none. The Resolution No. 287 is a surprising step by $\mathrm{CNJ}$ to effectively recognize the cultural and ethnic plurality of the original peoples of Brazil, although it maintains contradictions inherent to the challenge of overcoming the assimilationist paradigm. However, beyond any new registration protocols, any reduction in incarceration rates or any training of magistrates and adaptation of their services, any change will ultimately come from the outside, as Brazilian elites abdicate privileges coming from their whiteness.
\end{abstract}

Keywords: Indigenous Peoples; criminalization of Indigenous people; Indigenous Incarceration; Resolution No. 287 by National Council of Justice of Brazil. 


\section{Encarceramento de indígenas no Brasil e a resolução n. 287, do Conselho Nacional de Justiça}

\section{Resumo}

Este artigo tem como objetivo analisar a Resolução no 287 do Conselho Nacional de Justiça do Brasil (CNJ), que estabelece procedimentos especiais para o tratamento de indígenas acusados, réus, condenados ou privados de liberdade e mostra o necessário processo de garantia de seus direitos no Poder Judiciário brasileiro. Incentiva a reflexão sobre por que o impacto da referida Resolução nas representações sociais do Poder Judiciário brasileiro é quase nulo. A Resolução no 287 é um passo surpreendente do CNJ para efetivamente reconhecer a pluralidade cultural e étnica dos povos originários do Brasil, embora mantenha contradições inerentes ao desafio de superar o paradigma assimilacionista. Contudo, para além de novos protocolos de cadastramento, de redução do encarceramento ou de capacitação da magistratura e dos seus serviços, a mudança virá de fora para dentro na medida em que as elites brasileiras abdicarem dos privilégios da branquitude.

Palavras-chave: Povos Originários; criminalização de indígenas; encarceramento de indígenas; Resolução no 287 do Conselho Nacional de Justiça do Brasil.

\section{Encarcelación de indígenas en Brasil y resolución $n^{\circ} 287$ del Consejo Nacional de Justicia}

\section{Resumen}

Este artículo tiene como objetivo analizar la Resolución No. 287 del Consejo Nacional de Justicia de Brasil (CNJ), que establece procedimientos especiales para el tratamiento de indígenas acusados, imputados, condenados o privados de libertad y muestra el proceso necesario para garantizar sus derechos en el Poder Judicial brasileño. Estimula la reflexión sobre por qué el impacto de la mencionada Resolución sobre las representaciones sociales del Poder Judicial brasileño es casi nulo. La Resolución No. 287 es un paso sorprendente del CNJ para reconocer efectivamente la pluralidad cultural y étnica de los pueblos indígenas de Brasil, aunque mantiene contradicciones inherentes al desafío de superar el paradigma asimilacionista. Sin embargo, además de los nuevos protocolos de registro, la reducción del encarcelamiento o la capacitación de la magistratura y sus servicios, el cambio vendrá de afuera hacia adentro, ya que las élites brasileñas abdicarán de los privilegios de la blancura.

Palabras clave: Pueblos originarios; criminalización de los pueblos indígenas; encarcelamiento de indígenas; Resolución No. 287 del Consejo Nacional de Justicia de Brasil. 


\title{
Incarceration of indigenous people in Brazil and resolution no. 287 of the National Council of Justice of Brazil
}

\author{
Ela Wiecko Volkmer de Castilho \\ Tédney Moreira da Silva
}

\section{Introduction}

Little is known of the criminalization and sentence execution of Indigenous peoples in Brazil. The Federal Prosecution Office School (Escola do Ministério Público da União - ESMPU) commissioned a groundbreaking survey on indigenous incarceration between 2008 and 2009, which was made by the Brazilian Anthropology Association (Associação Brasileira de Antropologia - ABA). Unfortunately, the survey could not be continued: it should have been assigned to the National Indigenous Foundation (Fundação Nacional do Índio - Funai), which in turn should have continued to collect official data, but they never did. The Federal and State Prosecution Offices, the Federal and State Public Defenders' Offices and the Indigenous peoples or indigenist organizations have partial data on their particular jurisdiction, but such data has not been added to any system. The National Penitentiary Department (Departamento Penitenciário Nacional - DEPEN) is the most valuable data source from a quantitative perspective, since it gathers all the data from penitentiaries in all of the states and the Federal District. However, such data is inaccurate and does not include cases of deprivation of liberty sentences. Most recently, the National Council of Justice of Brazil (Conselho Nacional de Justiça - CNJ) created the National 2.o Prison Monitoring Database (Banco Nacional de Monitoramento de Prisões 2.0 - BNMP 2.0), a nationwide dynamically integrated database that is updated in real time by Federal and State Courts and Appellate Courts to manage the proceedings of defendants who are arrested and of people who have been sentenced to reclusion, even if they have no prior criminal record in the system (CNJ, 2020C). The National Council of Prosecution Office (Conselho Nacional do Ministério Público - CNMP) also created its database about the Federal and State Prosecution Offices and the Federal District Prosecution Office jurisdictions in order to inspect the imprisonment and incarceration system. Finally, the indigenous peoples decided to organize themselves around the creation of an Observatory of the Criminal Justice System and Indigenous Peoples, through the Articulation of the Indigenous Peoples of Brazil (Articulação dos Povos Indígenas do Brasil - APIB), whose work began within the second half of 2021 with the promise of carrying out a current work of surveying information.

We currently have access to a lot more information than we did 20 years ago, but researchers face difficulties when trying to access the data related to Indigenous people within the justice and public security records, and the absence or inaccuracy of such data is striking.

From that perspective, the enactment of Resolution No. 287 of 2019 by the CNJ, a government organ responsible for controlling the administrative and financial actions of the Judiciary Branch and for overseeing that judges comply with their duties, is uplifting news. The resolution presents the necessary procedures to properly treat indigenous people who stand as accused, defendants, or who have been convicted or received a deprivation of liberty sentence in Brazil by incorporating in its internal rules the constitutional and legal rules as well as the international human rights. 
However, the desired repercussion is yet to be achieved, because the assimilationist ideology concerning Indigenous peoples - from before this shift in paradigm brought by the Brazilian Federal Constitution for ethnic diversity - is still very much alive within decisions rendered by the Superior Court of Justice (Superior Tribunal de Justiça - STJ) and even the Federal Supreme Court (Supremo Tribunal Federal - STF), whose President also presides over the $\mathrm{CNJ}$.

The punishment of native individuals through incarceration shows the challenges of achieving a true equal interethnic relations in Brazilian society, one which resists the knowledge of its multiethnic roots and latches onto hierarchical structures from the colonial period that extended until the early $19^{\text {th }}$ century.

The silence in legal texts about this matter, the criminal procedure and sentence execution concerning native individuals that ignores their ethnic particularities under the short-sighted argument of assimilation based on the fact that such individuals speak the national language or live in urban areas, such silence is part of an ethnocide logic whose purpose is to erase any ethnic diversity.

In order to break the silence, we encourage you to reflect about the challenges of implementing Resolution No. 287 of 2019 in the Brazilian criminal justice system. The following is a list of the subjects that drive this research: 1) Why constitutional and international treaties texts have not been enough to change social representation and practices within the Brazilian Judiciary Branch in relation to native individuals that are charged of crimes defined under the State law?; 2) What is the capacity of a Resolution issued by an administrative control body to make the interpretation of judges and courts abandon the assimilationist paradigm and incorporate that of ethnic diversity established in the 1988 Constitution?; As hypotheses, we work, on the one hand, with the theory of coloniality of power that configures the structural racism of Brazilian society that denies the poor, black population and native peoples the condition of subjects entitled to rights. On the other hand, with Herrera Flores' critical theory of human rights, according to which it is possible to use the norms and the justice system to include subjects and themes in order to destabilize the current order, creating contexts favorable to economic and social changes that will establish a less unequal order.

We start by presenting Resolution No. 287 , its precedents and its observed effects. Next, we display data made available by penitentiary administration agencies about the Indigenous imprisoned population that is serving both unappealable and provisional sentences. We indicate the challenges set forth by the SARS-CoV-2 (new coronavirus) pandemic, whose devastating potential amongst Indigenous peoples has been largely ignored by the Brazilian Government, thus aggravating even more their imprisonment situation. This indefinite data collection method unveils the State's omission in properly implementing a criminal execution policy for Indigenous peoples, where indirect discrimination takes place. In the third topic, we analyze the possibility of reversing this situation through the CNJ's judicial policy. Our closing thoughts point towards the paths that can lead to an internalization of the diversity paradigm by the Brazilian Judiciary Branch and, consequently, the entire legal and public security system.

\section{The National Justice Council Resolution No. 287: precedents and effects}

The data survey carried out by ABA and Federal Public Prosecution (Ministério Público Federal - MPF), from 2000 onwards, displays the disproportionate number of incarcerations of indigenous individuals in some states, a situation that begs for a solution. The proposals went through different deliberation organs and displayed different thematic approaches of the issue (ranging from the Executive Branch with the possibility of issuing a collective pardon of sentence to legislative changes through the alteration of key procedural and criminal executive laws). 
Somehow, the presence of indigenous people in the prison system started being noticed as it has been noticed the need to "fix" the excess of criminalization through pardons and commuted sentences. We need to go further: a permanent and immediate policy to identify and assure the cultural rights of incarcerated indigenous people, such as the maintenance of their bonds to their respective communities, being able to express in their mother tongue, healing and meals methods according to their native customs, etc. (Castilho, 2019: 144) [free translation]

The most recent, and, so far, most far-reaching attempt to deal with the stigma of criminalization and high number of imprisonments of indigenous people was consolidated in the form of Resolution No. 287 of June 25, 2019 by the National Council of Justice (CNJ, 2019). The document establishes special procedures for the treatment of Indigenous peoples standing as accused, defendants, who have been convicted or deprived of liberty, and indicates processes to guarantee this population's rights within the criminal sphere of the Brazilian Judiciary Branch.

The Resolution's recitals point to the CNJ's respect for the international human rights guidelines for Indigenous peoples and the Brazilian Constitution of 1988 , and it could not be differently. It expressly mentions the 2016 Report on the Mission in Brazil by the UN Special Rapporteur on Indigenous peoples' rights, which recommended that the Legislative, Executive and Judiciary Branches urgently consider working along with the Indigenous peoples to eliminate the barriers that stop them from enforcing their right to justice.

The manual enclosed to the Resolution brought a presentation written by Justice Dias Toffoli, President of the CNJ. Such presentation reports that the CNJ:

[...] has organized a series of meetings with representatives from various organs and entities of the justice system, the Executive and Judiciary Branches, and from the civil society that intended to identify procedures to ensure that the criminal liability and sentence execution of indigenous peoples were compatible with the Brazilian constitution and international treaties signed by Brazil. (CNJ, 2019: 7) [free translation]

In considering that the role of the Judiciary Branch in the criminal context is not just to punish, but to preserve human rights, the $\mathrm{CNJ}$ determined that, in dealing with Indigenous peoples, whether they are Brazilian or not, should they be identified as such in any step of the criminal process, they must be approached with the application of special procedures that maintain their right to self-determination, and the use of Portuguese language or their native language, regardless of their current place of residence.

This measure also ensures other subjective rights of indigenous people, such as: the delivery of procedural records that should be forwarded the nearest Funai office in up to forty-eight (48) hours after their arrest; their right to add this information to the data system of the Judiciary Branch, especially the record of custody hearing (which verify the legality of the act that orders an arrest); their right of having interpreters, who should preferably be members of the same indigenous community as the defendant's while such interpreter should be in attendance in every step of the process when needed (CNJ, 2019).

The public organ was also concerned with determining that, whenever possible, either by praxis or by request of the parties to the proceeding, any judge may, when receiving a report or complaint against an indigenous individual, order an anthropological examination that will provide for elements necessary to define the criminal liability aiming at restricting discriminatory and arbitrary decisions based on ethnocentric judgment of the customs of ethnic groups. The anthropological report should determine the ethnicity, native language, personal, cultural, social, and economic circumstances, customs and circumstances of the defendant and how their native community construes the typical conduct imputed on the individual. Furthermore, the report should also inform whether there is any criminal alternative, meaning the agreements and resolutions undertaken by said individual's own native people (CNJ, 2019). 
Lastly, the Resolution encourages judges to attempt to apply proper conflict resolution measures of each Indigenous People, and should the sentence still require the deprivation of liberty, they should seek partnerships with Funai and other institutions to adopt and implement a special semi-free sentencing regime to respect the convicted person's ethnicity and attempt to reduce the deleterious impacts of a sentence that deprives liberty. The organ also incentivizes house-arrest for the indigenous people, considering their home as the territory or geographic boundaries of their community pursuant to a previous consultation.

We cannot overlook a contradiction in the wording of the Resolution because it invokes Convention No. 169, which reads that Indigenous peoples should be consulted in the issuing of norms that involve their interests. The organ itself, however, failed to summon indigenous organizations to express their opinion. This attitude reveals the understanding by the state organs that the representation of the Indigenous peoples is supplied through Funai, an indigenist organ formed under the assimilationist paradigm that considers Indigenous people as incapable of exercising their own rights and legal interests.

In any case, two years after the issuing of Resolution No. 287 of 2019, its guidelines are apparently not being followed by the Judiciary Branch. The number of provisional arrests has gradually increased in disagreement with the guidelines that call for their substitution with alternative measures, as well as the number of definitive arrests, ignoring the special semi-free prison regime recommendation. The incarceration of indigenous people without regard for their rights and legal guarantees reinforces the same penal functionality of suffocating ethnic differences and, consequently, shows a contempt for their social vulnerability status.

As an example, the decision by the STJ Justice João Otávio Noronha on the Habeas Corpus Petition (RHC) No. 113.309/BA on October 26, 2020 causes astonishment; one of its main foundations in an excerpt of the appellate decision by the Regional Federal Court of the $1^{\text {st }}$ Region:

As to the application of the special semi-free prison regime provided by the sole paragraph of Article 56 of Law No. 6,001 of 1973, the request is not granted, considering that such mitigating factor does not apply to an indigenous individual who, although he preserves his customs, is socially integrated and exercises his civil rights in full. Now, the petitioner took part in several land negotiations having frequently participated in Funai meetings and, therefore, no one can say that he lacks social integration. Still, the petitioner has real possibility of reengaging in crime or evading any culpability, which prevents applying any alternatives to prison, even a semi-free sentence regime available to Indigenous peoples (STJ, 2020).

If the resolution and the manual were followed, this decision would have been different, because the text reads that the criteria for recognizing a defendant as indigenous is self-declaration and that the "acculturated" or "integrated" typification have been banned from the Constitution of 1988. (CNJ, 2019: 16) [free translation] The manual text clarifies:

The fact that indigenous peoples have access to fundamental rights, such as public education, work, healthcare and transportation - rights granted equally to all under the Constitution - has no impact on their indigenous identity, and as such, it cannot be used as an argument to avoid granting them rights and legal guarantees specifically aimed at protecting Indigenous peoples undergoing criminal prosecution. (CNJ, 2019: 13) [free translation]

The aforesaid is similar to the STF $1^{\text {st }}$ Panel decision, taken by majority vote, on the Habeas Corpus Petition (HC) No. 183.598 of December 1, 2020, which denies a house arrest on humanitarian grounds to an elderly diabetic, hypertense and chronically ill indigenous man of the Guarani-Kaiowá community. He was, instead, sentenced to 18 years in prison on a fully closed prison initial regime (STF, 2020c). One of the points considered by the STF Justice-Rapporteur, according to statements by STF Justices Dias Toffoli and Roberto Barroso, 
is that, according to the case records, the indigenous man is acculturated, which prevents the individual from be recognized in his indigenous identity and therefore having his sentenced commuted into house arrest (STF, 2020c).

It is necessary, however, to recognize that Resolution No. 287 has had positive effects. In this sense, it is important to mention Technical Note No. 53/2019', still in process at the Ministry of Justice and Public Security (Ministério da Justiça e Segurança Pública - MJSP), through which the Department of Care for Women and Specific Groups (Divisão de Atenção às Mulheres e Grupos Especificos - DIAMGE) of DEPEN has the "goal of recommending state penitentiary management organs to adopt necessary and effective measures for Indigenous people incarcerated at penal establishments, in compliance with the international and national guidelines" (MJSP, 2019: 1) [free translation].

The Technical Note is the result of collaborative works among the National Criminal Services Ombudsman (Ouvidoria Nacional de Serviços Penais - ONSP) and Funai on the issues of incarcerated indigenous people about the individualization of their sentences, which expressly mentions the need to follow Resolution No. 287. The note lists a series of recommendations as an action protocol to be followed by penitentiary administration agents that covers the following: (I) Entry; (II) Registration; (III) Allocation spaces; (IV) Language; (V) Access to healthcare; (VI) Dietary habits; (VII) Religion; (VIII) Documentation; (IX) Registry of indigenous visitors; (X) Haircut; (XI) Educational activities; (XII) Work activities; (XIII) Gender specificities; (XIV) Capability of prison workers. If the Technical Note is approved by DEPEN's general management, it is expected to be notified to, among other organs, the National Council of Criminal and Penitentiary Policy (Conselho Nacional de Politica Criminal e Segurança Pública - CPNCP), the CNMP, the CNJ, the National School of General Public Defenders (Colégio Nacional de Defensores Públicos-Gerais - CNDPG), the National Mechanism to Prevent and Fight Torture (Mecanismo Nacional de Prevenção e Combate à Tortura - MNPCT). It is worth mentioning that the CNPCP and MNPCT are allowed to inspect and investigate penal establishments and file reports with relevant authorities in case of any violation of the sentence execution norms. The remaining organs establish standardized protocols to investigate or visit the prison system on behalf of sentence execution organs, as judges, members of the Prosecution Office or the Public Defender's Office.

In that context, the management of the CNJ by STF President-Justice Luiz Fux, between 2020-2022, set a transversal initiative called "Electronic Systems of the $\mathrm{DMF}^{2}$ and the Population in Vulnerable Situation." Its goal is to improve registration fields in digital systems, granting more visibility to these groups and producing data that allows the creation of legal policies against structural inequality. One of the vulnerable groups that attracts special attention is the Indigenous peoples. The initiative goes further in the actual implementation of Resolution No. 287, because it demands the diagnosis of digital systems maintained by DMF/CNJ to evaluate criteria of race, ethnicity, accessibility, gender, gender identity, sexual orientation and immigration situation; the correction of digital systems to help the user visualize the requirements and functionalities mapped out; the writing and publication of a manual for filling the registry properly; the dissemination of knowledge and educating users, and; coordinated action between Justice Courts and Regional Federal Courts to publicize the material and application of its content.

\footnotetext{
1 The Technical Note was proposed by DIAMGE with the General Coordination for Citizenship and Penal Alternatives (Coordenação-Geral de Alternativa Penais - CGCAP), both of them part of the Penitentiary Policies Department (Diretoria de Políticas Penitenciárias - DIRPP), the National Penitentiary Department (Departamento Penitenciário Nacional - DEPEN), was signed on December 6, 2019, by Susana Inês de Almeida e Silva, General Coordinator of Citizenship and Penal Alternatives and forwarded to DIRPP (MJSP, 2019).

2 Department of Monitoring and Supervision of the Prison System and the Execution System of Social-Educational Measures (Departamento de Monitoramento e Fiscalização do Sistema Carcerário e do Sistema de Execução de Medidas Socioeducativas - DMF), created by Law No. 12,106 of 2009.
} 
The standardization to which every unit of the Judiciary Branch is subject to could, in the next two years, lead to a successful collection of data on the number of indigenous people currently going through criminal proceedings and those who have been convicted, are serving sentence, as well as on criminal incidences, gender, age, and other markers. The theme of indigenous identity will be subject to increasing controversy, and it is our hope that it will be on a level that conforms to the principles of the United Nations' Declaration on the Rights of Indigenous Peoples (UN, 2007), of the ILO 169 Convention (ILO, 1989), and of the American Declaration on the Rights of Indigenous Peoples (OAS, 2016).

Considering the assimilationist and punitive ideologies that serve as the basis for the majority of the Judiciary Branch's arguments, as we will show in a topic below, it is relevant to attempt to understand how and why Resolution No. 287 was written, and analyze the effective possibilities of whether it can promote an ideological change in the Judiciary Branch that even the Brazilian Federal Constitution was not able to achieve, especially considering that the $\mathrm{CNJ}$ is not an organ that controls jurisdictional activities. However, it can be thought of as interventions in the organization of non-core activities and debate forums, and it can, for instance, leverage attitude changes. In that vein, we emphasize the creation of the Task Force named "The Judiciary Branch's Human Rights Watchers," by Ordinance No. 190 of July 17, 2020, which has as one of its members Maria Manuela Carneiro da Cunha, who had an important role in the discussion for the recognition of the original rights of Indigenous peoples (CNJ, 202ob). This Task Force can propose to the CNJ Full-Bench Panel measures they deem adequate to improve protection of human rights within the sphere of the Judiciary Branch. The presence of Professor Carneiro da Cunha will certainly contribute to the visibility of violations of indigenous rights by the justice system and help propose measures to stop them.

We have also identified the repercussion at the level of civil societies, such as the Brazilian Institute of Criminal Sciences (Instituto Brasileiro de Ciências Criminais - IBCCRIM), which created the Task Force named

"Indigenous Peoples and the Criminal System"and promoted, along with other entities, the publication of the "Educational Comics for incarcerated indigenous people and their communities" (Hilgert et al., 2020). This group, which counts on the help of indigenous lawyers, has been promoting debates on how to focus on the justice system to modify the interpretations that disregard ethnic specificity.

Finally, we point out to the recent formation by APIB of the Observatory of the Criminal Justice System and Indigenous Peoples, which will undeniably contribute to a direct representation by the aboriginal peoples of their interests in the subject.

\section{Indigenous incarceration in Brazil: the inconsistency of statistic data and omission by the State}

Incarceration is not just the result of the penal process that, logically and temporally, precedes it; before anything, it is the goal towards which the process unfolds. Sentence execution, as a peculiar field in criminology, is seen as the final step of concretization of criminal justice, in which those convicted will serve, for an amount of time defined by the Judiciary Branch, the imposed sentence as a form of punishment for the illicit act attributed thereto, and, simultaneously of resocialization. Construing it as a goal of criminalization leads us to study the reasons of selectivity in regard to those convicted and the particular conducts effectively punished.

Indigenous peoples have been targeted for incarceration mostly often for ideological or political biases that lead to prejudice and discrimination rather than on actual evidence of any unlawful conduct. This is a common trait in every country that was subjected to the violence of European colonization. In that sense, in comparing criminalization processes for Indigenous peoples in three different countries (Canada, Australia and New Zealand), Samantha Jeffries and Philip Stenning (2014:480) observe: 
Legislative and judicial approaches to the sentencing of Aboriginal offenders appear to be driven more by political and ideological considerations and aspirations, rather than by clear evidence. Unfortunately, none of the sentencing approaches adopted in any of the three countries can actually be shown to have led to any significant reductions in the statistical over-incarceration of Aboriginal people, which has increased rather than diminished since these various innovations were introduced.

Once the convict is identified as indigenous people, in accordance to article 56, sole paragraph, of Law No. 6,001 of 1973 (Indian Statute): "the reclusion and detention sentences will, if possible, be served in a special semi-free regime, located in the nearest working place of federal government bodies tasked with assisting Indigenous peoples to the person in question" (Brazil, 1973). There are no specific procedures in the special law, apart from the definition of mitigating any penalty enforceable on the indigenous people and the provision of their own prison regime, specific procedures regarding the criminalization of indigenous people in the course of the criminal proceedings. Funai workplaces no longer has the physical structure and human resources for such and, therefore, Indigenous peoples are sent to common penitentiaries in a closed or semi-open prison regime, the latter of which should not be mistaken for the semi-free regimes that have never been regulated. In legal terms, it violates the subjective rights of those indigenous people convicted of a crime, because, due to the State's omission, they are serving a harsher sentence than required by law.

The exact number of Indigenous people prosecuted through the criminal justice system is unknown. Prison data, on a national level, is collected and sorted by the National Penitentiary Information System (Levantamento Nacional de Informações Penitenciárias - Infopen) $)^{3}$, a part of DEPEN. The reasons for such uncertainties towards the data by Infopen are threefold: Firstly, in each federative unit, different organizations and public agents are tasked with the collection and processing of data, and there is no standardization in responsibility or method of collecting it; secondly, it is unclear how the matter of race or ethnicity of the inmates is answered in each survey, that is, if the person self-declares as such or if a third party establishes who is part of a certain group, according to subjective criteria; thirdly, there is no information on what type of criminal behavior each indigenous people inmate has been trialed for - both under provisional and definitive arrests - or if they are awaiting trial or serving their sentences in special prison units. For these reasons, Christian Teófilo da Silva (2009: 213) is quoted saying

[...] Infopen's quantitative data should interest us less as a trustworthy record of the totality of Indigenous inmates currently incarcerated, but more as eye-opening data on the use of ethnic and legal classifications within the system of processing and management of penitentiary data in Brazil. [free translation]

According to Infopen's last update (MJSP, 2020b), Brazil's prison population - temporary detention excluded - reached the level of 748,009 people4, relative to the period from July to December 2019, with 657,844 of them being identified by ethnic and racial criteria. From these, $0.21 \%$ are Indigenous, which equals 1,390 people (MJSP, 2020a) 5 . The following table presents the absolute number of Indigenous peoples in incarceration in the period from June 2016 to December 2019.

\footnotetext{
3 Infopen is a database that registers general and preliminary indicators about the prison populations in Brazil and is intended to inform the adequate public bodies the measures that should be necessary to outline specific public policies.

4 The total number, including in carcerary units and temporary holdings, amounted to 755,274 people.

5 On the other hand, the Prison Monitoring Board of the CNJ, updated every day with data relayed from state courts, registered on July 13 , 2020, that the number of people incarcerated was 875,659 , from these, 289,701 are provisional prisoners (44\%)
} 
Table 1: Indigenous peoples incarcerated in Brasil

\begin{tabular}{|c|c|c|c|}
\hline Semester & Male prisoners & Female prisoners & $\begin{array}{c}\text { Total number of } \\
\text { Indigenous folk } \\
\text { incarcerated }\end{array}$ \\
\hline June.2016 & 552 & 38 & 590 \\
\hline December.2016 & 613 & 41 & 654 \\
\hline June.2017 & 1,106 & 81 & 1,187 \\
\hline December.2017 & 1,022 & 68 & 1,090 \\
\hline June.2018 & 745 & 45 & 790 \\
\hline December.2018 & 1,148 & 53 & 1,201 \\
\hline June.2019 & 1,218 & 78 & 1,390 \\
\hline December.2019 & 1,325 & 65 & \\
\hline
\end{tabular}

Source: Ministry of Justice and Public Security, 2020.

The Technical Note No. 77/2020 by DEPEN, in dissociating the data pertaining to the 1,39o prisoners in December 2019, points that the state with the largest number of indigenous people incarcerations is Mato Grosso do Sul with 349 in total belonging to the Guarani-Kaiowá, Terena and Kadiwéu ethnicities. The state of Roraima comes second place with 110 from the Macuxi, Wapixana, Ingarikó, Tikuna, Yanomami, Taurepang and Guiana ethnicities ${ }^{6}$. The state of Rio Grande do Sul comes third with 64 people from Guarani, Terena and Kaigang ethnicities (MJSP, 2020). The Technical Note registered that, out of the 1,39o, less than half (672) indicated their ethnicity (MJSP, 2020a).

There is a noticeable, progressive increase in the number of indigenous arrests - except for a brief decrease in the second half of 2017 - until the first half of 2018 when it began to rise again.

Both DEPEN and the CNJ have sought to improve data collection methods, including those pertaining to race/color and ethnicity. It is a relevant task, for the lack of reliable data on indigenous incarceration in Brazil causes the issue to go unnoticed, which, in turn, further contributes to the vulnerability of this social segment and making the adoption of proper public policies even more difficult.

The following graphic shows the peaks at each half-year of incarceration of indigenous men and women throughout Brazil, according to data from the surveys made by DEPEN from December 2005 to December 2019. It should be noted, however, that the DEPEN did not provide the reports on the half-year periods from June to December 2013 and from January to June 2015.

6 Most likely pertains to one of the ethnicities whose territory is on or near the border (Macuxi, Taurepang, Yanomami), with Guyanese citizenship. 


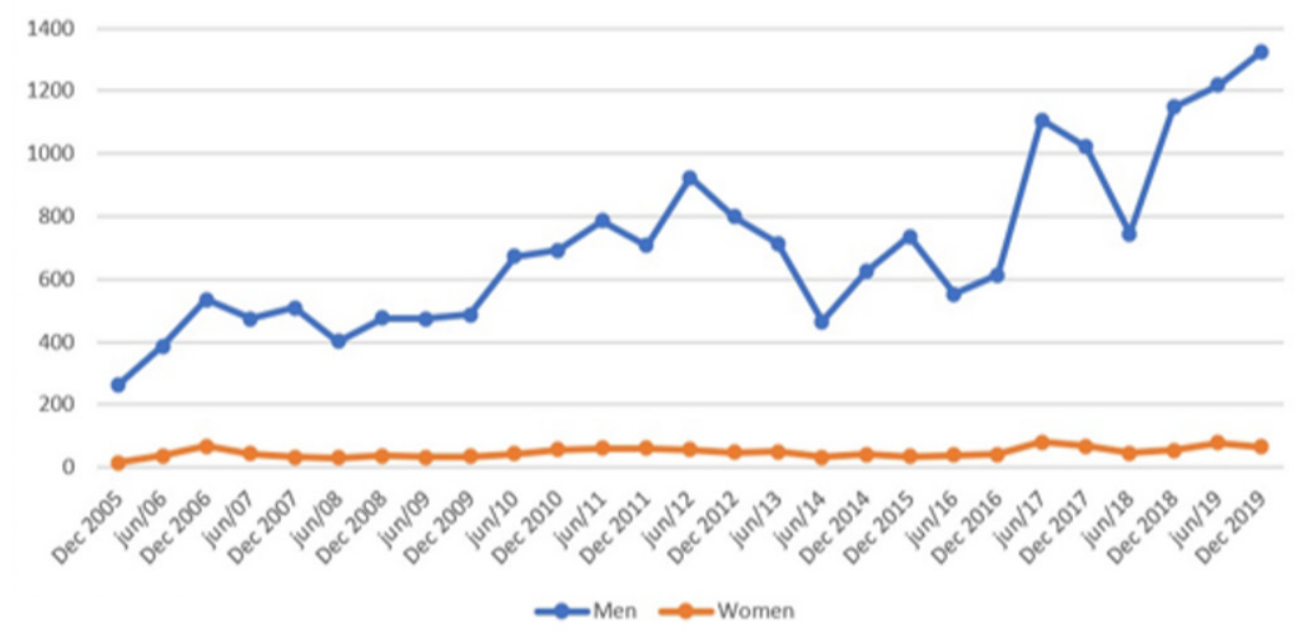

Source: MJSP, 2020

There has been an increase in the last two years (from 2017 to 2019), which may in fact express an increase or only the recognition of previously unidentified indigenous people, without knowing whether self-recognition has been respected or whether there has been indicated an ethnic identity by civil servants.

Daniele de Souza Osório, when revisiting the 2010 Census data (2020: 39), in regional terms, pointed out the following percentage distribution of indigenous prisoners: Midwest (37.62\%), North (21.70\%), Northeast $(18.31 \%)$, South (15.93\%) and Southeast (6.44\%). She also indicates that Mato Grosso do Sul is the state with the highest number of indigenous people incarcerated: in absolute numbers, there are 73,295 self-declared indigenous people, especially the Atikum, Guarani Kaiowá, Guarani Ñandeva, Terena, Kadiwéu, Guató, Ofaié and Kinikinau (Osório, 2020:39)

As previously stated, both DEPEN and CNJ have sought to improve data collection methods, including race/color and ethnicity. A relevant task, because the lack of reliable data on indigenous incarceration in Brazil makes the issue go unnoticed, which, in turn, contributes even more to the vulnerability of this demographic group, making it more difficult to adopt adequate public policies.

In 2020, with the outbreak of the COVID-19 pandemic, the lack of reliable data was very damaging to those indigenous individuals in incarceration due to the fact they were being kept in establishments known for being unsanitary presents an increased risk of exposure to the entire prison population, especially those of indigenous ethnicities. Although SARS-CoV-2 (new coronavirus) is a novel virus to which there is no previous immune response to non-indigenous people, scientific studies point to an increased vulnerability in an epidemiological standpoint, on account of their historical social, economic, healthcare and food restrictions (Valverde, 2020).

For that reason, Indigenous peoples were expressly included by the CNJ amongst the risk groups for the purposes of Recommendation No. 62 of March 17, 2020, which regards preventive and combative measures against the COVID-19 pandemic in the prison and social-educational systems (CNJ, 2020a).

The number of indigenous people benefiting from the Recommendation with the substitution of preventive detention for alternative measures or progression from a sentence to a semi-open or open prison regime or even under house arrest has not been made available by CNJ or DEPEN.

Questioning the omissions by the Brazilian Federal Government in the fight against SARS-CoV-2 amongst Indigenous peoples, the APIB filed with the STF the Fundamental Precept of Non-Compliance Complaint No. 709/DF (Arguição de Descumprimento de Preceito Fundamental -ADPF No. 709/DF) along with several political parties with the purpose of questioning commissive and omissions by the Brazilian Public Administration 
concerning the fight against COVID-19. Amongst the various subjects approached by ADPF No. 709/DF is the concern with indigenous people who are currently incarcerated, and STF was requested to order the Federal Government to adopt urgent sanitary measures for the prevention and treatment of COVID-19 cases amongst Indigenous peoples to the entire country. STF Justice Luís Roberto Barroso recognized that APIB has legal standing to sue and determined, on a preliminary basis, a plan to fight COVID-19 amongst Indigenous populations should be implemented with the participation of the communities (STF, 202ob).

In the meantime, ADPF No. 684 filed by the political party PSOL on May 11, 2020 was not reviewed by then STF Justice Celso de Mello, and the lawsuit still awaits an analysis by his successor, STF Justice Nunes Marques. The lawsuit purpose is to have the Court acknowledge the breach of fundamental precepts in penitentiary management, especially with regard to healthcare, life and general safety of the prison population, its workers, and society at large, in light of the State's failure to contain the proliferation of the COVID-19 pandemic in the prison system (STF, 2020a). The lawsuit requests, on a provisional basis, the Secretaries of Penitentiary Administration (or other secretaries with similar purposes) within state level, and DEPEN within the federal level, and the Groups for Monitoring and Administration of the Prison System (Grupos de Monitoramento e Fiscalização do Sistema Carcerário - GMF) of state courts, be ordered to publish accurate information on the healthcare and installation situation of indigenous prisoners, according to article 12 of Recommendation No. $62 / 20$ by the $\mathrm{CNJ}$ (CNJ, 2020a).

Finally, it is undeniable that the reliance on punishment through normal regime incarceration overwhelmingly impacts the reinsertion of Indigenous peoples into society, according to their customs and cultures. Examining the effects of incarceration on Indigenous peoples who were criminalized in Canada, Davinder Singh et al. (2019: 488) remark that:

Incarceration negatively affects social determinants of health, such as employment and career prospects, relationship stability and housing status. Lack of access to these social determinants also increases risk of involvement in the criminal justice system, creating a cycle of poor health and vulnerability for criminal justice involvement. These issues are compounded for Indigenous Peoples, given their historic and current experiences of racism and social inequality. [free translation]

Such deleterious effects mark the experience of punishments that disregard ethnic diversity and the respect to the multitude of ways to solve and settle conflicts in society, which ends up electing the punitive power of the State as the only means to resolve such issues, given its concealed function of gathering and maximizing political power.

\section{The Coloniality of power and the critical theory of human rights as interpretative keys to the challenges and achievements of Resolution No. 287 of 2009}

In the previous topics, we brought to debate the CNJ's Resolution No. 287 that recognizes that it does not integrate the updated Penal Code, the Procedural Penal Code or even the Indian Statute to incorporate paradigm changes on the issue of respect to Indigenous Rights introduced by the Brazilian Federal Constitution of 1988 , leaving several gaps to criminal and legal proceedings for indigenous people who stand as accused, defendant and has been convicted for a crime. It identified procedures to ensure the actions of criminal liability or enforcement of sentence on indigenous people are compatible with the Brazilian constitutional text, as well as international treaties signed by Brazil (CNJ, 2019: 7).

The question that arises is: why have the Brazilian Constitution and international treaties not been sufficient to change the social representations and practices of the Brazilian Judiciary Branch in relation to indigenous people accused of crimes defined under the State law? From this perspective the following question arises: 
what is the capacity of a Resolution issued by an administrative control body to make the interpretation of judges and courts abandon the assimilationist paradigm and incorporate that of ethnic diversity established in the 1988 Constitution?

In this topic we seek to answer these questions from the theory of Coloniality of power, by Anibal Quijano (2000), which allows us to understand the construction and the permanence of social relations of European domination over the peoples originating in the Americas, and the critical theory of human rights by Joaquín Herrera Flores (2008), which makes it possible to understand its role as a counter-discourse, even if given the limitations of the edition of the Resolution.

Quijano identifies coloniality as an element that is specific to the constitution of the worldwide pattern of capitalist power. It is based on an ethnic/racial classification of the peoples of the world, like an axis outlining this pattern of power, which operates within several scopes and (material and subjective) dimensions of daily social existence, originating and spreading globally starting from Latin America (Quijano, 2000: 342). Colonialism and modernity are intertwined, having Eurocentric hegemony and modern rationality serving as a base, the latter being the only rationale compatible with the cognitive needs of capitalism (Quijano, 2000: 343). Eurocentrism does not constitute the ideals of just Europeans or those who benefit from power in global capitalism, but also of those who were taught under its hegemony, which normalized the experiences of those who live in this power structure, one that was held up by the myth of European superiority, with Europe and its citizens being the most advanced in a linear, continuous, and unidirectional path for humanity (Quijano, 2000: 343).

A central characteristic of coloniality and Eurocentric modernity is the concept that humanity is classified in such terms as: inferior versus superior, irrational versus rational, primitive versus civilized, traditional versus modern (Quijano, 2000: 344). The author states that the racialization of relations is an important point for understanding coloniality. Such concepts allow us to better understand how the annihilation of the Indigenous peoples of the Americas was set, and the social and judicial theories that were - and still are - used to justify the belittlement of their way of being, how they do things, how they live. Among such concepts is Augusto Comte's positivist philosophy that is still present in the common sense of Brazilian jurists.

Comtean philosophy stated that humanity progressed through three evolutionary stages: the theological stage that characterizes societies with both thinking and social structure mythological; the metaphysical stage that defined the revolutionary Illuminist impulse in the end of the $18^{\text {th }}$ century; finally, the positive state that describes societies dictated by a scientific thinking and the assumption of a "straight line" developmental order.

Positivist philosophy advocated the application of the biological theory to explain social inequality within a global and multicultural context - thus it began to be referred to as social Darwinism - even though Darwin never applied his theory in biological field to the social and political fields. According to Auguste Comte, humanity marches towards continual progress, which is only possible due to the adoption of scientific rhetoric to explain the differences between nations. This view, in turn, made it possible to talk about backward (or primitive) societies, or developing and civilized (or positive) societies, the latter being represented by Western European societies. According to John Corr (2014: 99):

Comte's design for society, a form of humanitarian authoritarianism, foresaw that government would be directed by the naturally powerful, those who produced wealth in the capitalist economies. Their governance values would be based on the scientific method, which would produce conclusions in all areas of knowledge so obvious that all of society would accept them. The scientific method would discover society's laws of operation, thereby giving society's governors the ability to make decisions conforming to what would be best for society. 
Two-thirds of the Comtean motto (Amour, Ordre et Progrès), are present in the Brazilian flag indicating that the formation of the Republic, in the end of the $19^{\text {th }}$ Century, not only imported Comtean ideals, but it also molded State institutions and defined how political power is used in the country.

In the field of criminology, positivist lessons began to be taught in the Law Schools of Recife and São Paulo, and in Bahia’s Medical School, by Adelino Filho, Aurelino Leal, Clóvis Bevilácqua, Pedro Lessa and Roberto Lyra; all important thinkers in the national legal field. They upheld Comtean ideals as the most adequate ones to the formation of the republican regime, established in the country by a civil and military coup in 1889 , whose first President was a Marshal and fellow positivist, Deodoro da Fonseca.

The intellectual elites, with the goal of modernizing themselves with the latest philosophical theories of the time, and at the same time, instrumentalizing the exercise of political power in a society with wellestablished hierarchies, viewed Positivism as a self-evident truth. In the Comtean thought, the concept of a criminal was based on racial, gender and class inequalities that structured national formation, which became an alleged scientific stage that explained the nature of criminals. According to Don Weatherburn and Mark Findlay (1985: 194):

There is no doubt that the constraints positivism imposed upon theory dramatically affected the character of what could be classed as legitimate criminological (or social) explanation. Theoretical attention turned almost exclusively to the task of identifying the correlates (e.g. broken homes, personality traits, etc) of deviant or criminal behavior. There was no sense in asking, save for purely heuristic purposes, what the deviant or the criminal had to say about his or her own behavior. Such verbalization was considered (at best) a kind of epiphenomenon lying between the real cause and effect of environmental conditions and observable response.

However, criminological knowledge was not derived directly from Comtean writings, but from the works of Italian writers inspired by them, who also became influent in the national legal academy. Among them are Cesare Lombroso, Raffaele Garofalo and Enrico Ferri, as the main builders of a criminal epistemological framework that linked crime and its occurrence to the nature of its perpetrators with the intent of affirming biological determinism in the criminal act.

Positivist criminology rooted in the ideals of social defense "(...) attested to delinquent personalities through the discernment of what it called 'anthropological signals' of crime, which made treating the 'evil' contained in potentially criminal people through penal intervention". (Santelli and Brito, 2014: 70) [free translation] In that sense, those who committed a crime would by nature be described as having a defective and incorrigible biological and psychological constitution, thus being the State's responsibility to either incarcerate them definitively or neutralize them.

Although beyond such measures, Indigenous peoples were also looked at through these extremes; they would either not being capable of committing any crime (for total lack of capability, due to their 'savage' state, according to the hypothesis of the bon sauvage), or they would concentrate all the criminological factors on themselves (considering what Lombrosian theory calls congenital atavism).

Thus, Indigenous peoples were considered the bearers of the evils of crime, part of societies that are primitive and barbaric, which preceded European civilization; the latter of which was seen as the tried-andtrue example of civility (Leão, 1913: 135-136). Other professors and jurists also contributed to the consolidation of the criminal stereotype attributed to indigenous people, with particular mention of Nina Rodrigues, who is the most dedicated to examining the causes of criminality according to positivist criminality perspective. In his essay, entitles "Human races and criminal liability in Brazil," published in 1894, black and indigenous populations represented atavistic species, ones that perpetuated mental and physical characteristics of primitive peoples, and as such, were so themselves. Even though his theories relied on a biological determinism to explain criminality among Indigenous peoples and black communities, Nina Rodrigues (1984 [1894]: 85) 
considered it of great importance to adopt a punitive correctional stance in which there were different degrees of punishment to the imprisoned person, varying in accordance to their proximity to whites. He emphasized that Indigenous peoples were especially incapable of being held criminally liable as others, because, he stated, that they would always lack the necessary psychological development to understand what they did. His arguments on indigenous liability reinforced the bias of their incompleteness; in broad terms, Indigenous peoples started being considered atavistic or of delayed mental formation.

The transposition of these etiological findings into legal dogmas started with a proposal by Nelson Hungria on the necessity of formulating a new Penal Code in the 1930's. In his work "Comentários ao Código Penal", Nelson Hungria (1958: 330) defended the hypothesis that Indigenous people should be treated as though they were people with mental disorders, being considered as such for practical legal purposes " [...] Homo sylvester, entirely devoid of the same ethic acquisitions as the civilized Homo medius, which penal law states is legally responsible." [free translation]

Nelson Hungria thought unnecessary to explicitly mention Indigenous peoples in the law, since they would logically be inferred to belong to the same category as other non imputable individuals - or those who cannot be held legally liable because they cannot fully comprehend or do not know how to determine their own actions according to their understanding.

The non imputability criteria would then take precedence in legal doctrine, when analyzing the culpability of indigenous defendants, with no further elaboration on the legal used for recognizing them as such or not. Although not explicitly stated in legal texts, the link between the inimputable status and Indigenous peoples was reproduced by teachers of penal law, thus, influencing the decision making in trials where the defendant declared their Indigenous ethnicity.

Surveying caselaw rendered until December 2014 (Silva, 2015), 319 court decisions within appellate sphere were found throughout Brazilian territory', which regarded the rights of indigenous defendants, thus requiring full-bench bodies to speak on the importance of ethnic identity when determining criminal liability. In $25 \%$ of cases (8o cases), the accused's defense requested the production of anthropological expert reports to infer the level of influence of ethnicity in the criminal act, thus appealing trial court decisions that had precluded the Indigenous ethnicity argument based on superficial and discriminatory criteria (such as the fact the defendant speaks Portuguese, works a regular job, or even watches television). In $22.6 \%$ of decisions ( 72 cases) ${ }^{8}$, the defense petitioned for a specific prison regime for indigenous inmates (semi-free regime found in Law No. 6.001, from 1973 [Statute of the Indian]), but, in every decision, the request was denied on the grounds that the defendants were no longer indigenous (Silva 2015: 161).

In a research conducted with similar methods (Cordeiro et al., 2020), encompassing criminal cases between the years of 2004 - year of the publication of the ILO 169 Convention in Brazil - and 2020, 18 appellate decisions were found that applied the semi-free sentence regime among the 153 analyzed appellate decisions. In the case of appellate decisions that refused the application of semi-free regime, the arguments used mostly focused on saying the indigenous individual was already integrated in society or that article 56 did not forbid the sentencing the individual to a closed prison regime because the article contains the expression "if possible."

\footnotetext{
7 Due to the federalist model adopted by the Brazilian Constitution, the Judiciary Branch is organized on the levels of states, the Federal District, and the Union. 215 court decisions were examined from States' and the Federal District's Courts of Justice, 38 from the five Regional Federal Courts, and 66 court decisions from upper courts, Superior Justice Court and the Supreme Federal Court.

8 The other cases ruled on a variety of issues; the indefiniteness towards the trial of cases that involve Indigenous individuals, whether they are of state or Federal jurisdiction (22,88\% of decisions, or 73 cases); the application of sentence reduction or pardons, given the defendant's Indigenous ethnic identity ( $16,6 \%$ of decisions, or 53 cases); the need for the intervention by Funai - an indigenous tutelary body - in the procedural hearings ( $6,9 \%$ of decisions, or 22 cases); the application of criteria of non-imputability in regards to responsibility of Indigenous peoples who are accused of a crime (4,4\% of decisions or 14 cases), and the right of defendants to attend trial whilst free ( $1,6 \%$ of decisions or 5 cases) (Silva, 2015)
} 
As for the appellate decisions in which the semi-free sentencing regime was applied, most of them did not specify how that would be done, and imposed that Funai dealt with all the necessary actions to enforce the decision. The grounds for applying these sentences, in accordance with article 56 of Law No. 6.001/73, were that the regime is applicable not only because the individual was indigenous but always, and above all, because it was a compliance with the $3^{\text {rd }}$ paragraph of article 33 of the Penal Code, and as a consequence of the attenuation granted by the new writing of the $1^{\text {st }}$ paragraph of article 2 of Law No. 8.072/9o, enforced through Law No. 11.464/07.

Thus, the process of criminalization of indigenous people is done without proper regard to ethnic diversity (and the impacts brought by such differences make in adequately defining legal liability); it is a process of State punishment, which, truth be told, violates the equality principle by promoting indirect discrimination. According to Andy Yu (2019:3), if doctrinal texts and international treaties fail to conceptualize and differentiate between direct and indirect discrimination, it is up to international courts to identify the subtle differences between them, based on both identifying factors of discriminatory patterns, and the intention of the discriminating agent in each case. Thus: “(...) direct discrimination involves a standard that facially discriminates based on a prohibited ground. Conversely, indirect discrimination involves a standard that is facially neutral and nonetheless differentially and adversely impacts a group identifiable by a prohibited ground."

Even if there is no explicit discriminatory motivation, the apparent neutrality the Brazilian Judiciary Branch shows in criminalizing Indigenous peoples by following the same patterns used for non-indigenous defendants, results in discrimination, especially when the criminalizing process is done through an ethnocentric perspective by a judge who interprets an indigenous individual as someone who has been assimilated into the national cultural hegemony, or who should be assimilated. This practice constitutes a biopolitical strategy of denying ethnic diversity through the exercise of a "civilizing punishment" (Silva, 2015), in other words, a criminalizing discourse that communicates the so-called success of the project of integrating or assimilating Indigenous peoples into the national unity.

Thus, the incarceration of Indigenous people unveils, the hidden political ends of the exercise of the State's punitive powers, which was not fully detached from the hierarchical and colonizing project disseminated here in the Americas; one that, in these terms, states that ethnic diversity is an evil or danger to be eliminated.

This racist mindset is a basis of Brazilian society. Overcoming it demands a deep social change, one that goes beyond changing laws, norms, and public policies (Almeida, 2018); that is due to the factor that keeps this mindset present in the structure of Brazilian elites. Goés (2018: 87) explains that:

[...] due to the particularities of the formation of Brazilian society, it formed a bourgeoisie that was entwined with foreign capital, incapable of developing productive forces and conducting the processes to develop an autonomous Brazilian form of capitalism. For that reason, it needs to be anti-democracy, and oppose any demonstrations by lower classes. [free translation]

Changing that configuration is an ongoing challenge. State institutions normally function in the perspective of its dominant social segment, they are "essentially conservative, always attempting to reproduce the same individuals and behaviors." The conservative aspect:

[...] restricts results of efforts to democratize its structures through policies that promote equality. It is not rare for the organization to reject diversity of behaviors and thoughts. It resists ethnic, gender, sexual orientation, among other diversities, in places of power (Bento, 2018: 120) [free translation] 
Members of the Judiciary Branch are also part of the Brazilian elite, and of an essentially conservative institution, although half the magistrates are up to 46 years old. Considering the age groups by segment of the Judiciary Branch, the youngest are in Federal Justice, with only $9 \%$ of the magistrate being over 56 years old. A little over half of the magistrates were born in São Paulo. Minas Gerais takes the second spot with 9\%; Rio Grande do Sul, Rio De Janeiro and Paraná are next, with 8\%. Most magistrates (59\%) operate in the state they were born. As to ethnic and racial identities, most declare themselves white $(80,3 \%), 18,1 \%$ black $(16,5 \%$ Pardo and 1,6\% black), and 1,6\% of Asian descent. Only 11 magistrates consider themselves Indigenous. Between those who entered until 1990, 84\% declare themselves white. Of those who entered between 1991-2000, that number is $82 \%$, reduced to $81 \%$ between $2001-2010$, and that number is at $76 \%$ between those who started their career from 2011 onwards. Ethnic and racial diversity is slightly higher among the Labor Justice magistrates when compared to state-level and Federal Justices; it is also higher among men than it is among women. The states of Piauí, Sergipe, Bahia, Maranhão and Acre have a number of at least $40 \%$ of magistrates that declare themselves as pardo or black. In Roraima, $3 \%$ of magistrates declare themselves to be Indigenous (CNJ, 2018).

The sociodemographic profile of magistrates clearly shows the scale of the transformation that is needed, since it is, in its majority, male and white, and although half of them belong to the generation of the 80's and were educated legally in a context after the Brazilian Federal Constitution, that fact alone was not enough to incorporate the paradigm of ethnic diversity.

In Adorno's view (apud Pastana 2012: 188), among judges, "with few exceptions, the most predominant interests are conservative when it comes to controlling the social order, the repressive containment of crime, and in questions of public safety." Even when they tolerate addressing human rights, they frequently doubt alternative solutions and the trust in democratizing policies. "Quite the contrary, they emphasize retributive policies that apply the most punitive rigor, if possible, contained in penitentiaries and restrictive of liberty" [free translation].

The prevalence of decisions that deny the right of Indigenous folk to a semi-free sentencing regime - or any condition that is perceived as less severe - is an example. It shows the resistance the Judiciary Branch shows to recognizing differences as a right in the concretization of substantial equality, that is, resistance to interpret in accordance with the Constitution and international treaties, indicating that, although it has presented itself as an important step towards the deconstruction of the assimilationist paradigm, Resolution No. 287 of 2019 runs the risk of constituting the exception within a long-established set of rules.

Nonetheless, it is important to recognize at the same time its important symbolism as a movement in favor of a decolonial critique of the criminal legal system. Although considering the limitations of the measure, the Resolution presents itself as an important counter-speech, given the fact that it was produced within the National Council of Justice, constitutional body in charge of control, the improvement and administrative and procedural transparency of the organs of the Judiciary Branch.

In this sense, regarding the possibility of promoting and defending human rights from internal and international legal instruments, as a way to consolidate the achievements of social movements' struggles, the considerations of Joaquín Herrera Flores (2008) constitute the theoretical basis for reflecting on the capacity of Resolution No. 287 to make the interpretation of judges and courts abandon the assimilationist paradigm and incorporate the constitutional and supraconstitutional of ethnic diversity.

Pursuant to Herrera Flores (2008: 134), it is possible to "[...] build normative proposals and realize social practices that can be used to transform such hegemonic systems and propose the search for real and concrete native alters if we perceive that they lead to injustices and exploitation of the human being". [free translation] As a result, the resolution is within a set of measures that formalize within the State's logic that contribute to represent the resistance to hegemonic narrative that excludes any and all form of diversity. As Ela Castilho (2021: 184) sums up, Joaquín Herrera Flores understands that 
[...] the legal system is shaped by the material and social context in which it is inscribed. Under these conditions, the interpreter, as a jurist, should be aware that his actions shape this context, a fact that can allow the claims of social struggles to be legally recognized and translated into the form of rights. [free translation]

The Resolution constitutes an important step towards accepting the social demands for recognition of ethnic diversity, although, paradoxically, the main criticism to be made of the Resolution lies in the fact that it was drawn up without the prior hearing of the indigenous, which reaffirms, in practice, a tendency to the extent that they can be represented by bodies responsible for the exercise of the tutelary Indian policy. The paradox, however, is emblematic of these clashes of contradictory political narratives, demonstrating that the obstacles to the realization of the human rights of the original peoples are many, but in the process of gradual deconstruction.

\section{Closing thoughts}

Indigenist integrationist policies act in maintaining interethnic barriers, building the consolidated views on Indigenous ethnicity, reinforcing a transitory nature to Indigenous peoples, to cover their stories of fighting, resistance and political struggles for autonomy. Be it to forever link them to the long-gone past of the colonial civilizational march (of white European persuasion), be it to frame Indigenous peoples as a perfect symbol of humanity, uncorrupted by society, coloniality paints (and still does) the outlines of indigenous people, whilst ignoring their voices, their bodies, and their acts of resistance to colonialism.

The construction of such image serves the purpose of denying, silencing, and erasing Indigenous history and putting it in a status of inferiority imposed to non-whites. In the field of criminology, as seen above, this view found space in physical anthropology developed in the early $19^{\text {th }}$ Century, which attributed an atavistic nature to indigenous individuals preventing them from being considered civilized; one that was disseminated in Brazil by importing ideas from positivist theories and social evolutionism. On the other hand, in the field of Indigenous policies, the same image was construed by means of integrationism or cultural assimilationism, and it worked (as still works) as a mechanism to deny ethnic diversity, downplaying the importance of indigenous people as true subjects entitled to rights.

As non-subjects, Indigenous peoples have their subjective rights denied and pending on legal definitions described by non-indigenous parties. By denying Indigenous subjectivity, integrationism operates ethnocide.

The CNJ took an important step with the publication of Resolution No. 287, which definitively points to judges what to do and how to fulfill the Constitutional text and international treaties on human rights. However, given its resolutive and administrative nature, the scope of the measure is limited to its role of challenging the institutional racism present in the Judiciary Branch. Recognizing the importance of the debate it promotes, Resolution No. 287 is not capable of by itself changing the course of the long-term phenomenon of assimilationism that marks Brazilian Indian politics, even because, even when well-intentioned, used it for the construction of its proposal, considered the direct non-avoidance of the indigenous in free, prior and informed consultation. The haste in the adoption of the resolution may be justified in the use of an administrative composition of the staff for the purpose of renewing the State's obtuse procedures, proving, however, that haste is not a sure way to change so consolidated integrationist bias.

In any case, it cannot be denied that the enactment of the Resolution No. 287 has an undeniable provocative and critical effect of the legal and administrative instruments available to the lawyer who deals with the criminalization of indigenous people: it constitutes an important counter-speech in favor of a narrative more focused on the recognition of ethnic diversity and respect for indigenous people as subjects entitled to rights. Moreover, by establishing an obligation to insert data into electronic systems operated by the CNJ 
- and the correct filling out of it by the responsible parties - will give more visibility to the particularities of Indigenous peoples and generate data that will allow the creation of more effective legal policies to fight structural inequality.

It cannot be overstated that undoing five centuries of colonialism and Eurocentric power structures will take some time. However, the process can be expedited as Brazilian elites knowingly abdicate their privileges or if they are sufficiently pushed by the lower classes to do so.

Received: January 25, 2021

Accepted: October $1^{\text {st }}, 2021$

Translated by: Maíra dos Santos Silva

\section{References}

ABA - Associação Brasileira de Antropologia. 2008. “Criminalização e Situação Prisional de Índios no Brasil: Edital Projeto de Pesquisa ESMPU no19/2006). Relatório Final”. Brasília: Procuradoria Geral da RepúblicaPGR e Associação Brasileira de Antropologia-ABA. Mimeo.

. 2009. "Processos de criminalização Indígena em Roraima/Brasil: Edital Projeto de Pesquisa ESMPU no 98/2007”. Brasília: Procuradoria Geral da República-PGR e Associação Brasileira de Antropologia-ABA. Mimeo.

ALMEIDA, Silvio Luiz de. 2018. "Estado e direito: a construção da raça”. In: SILVIA, Maria Lúcia da Silva et al. (orgs.), Violência e sociedade: o racismo como estruturante da sociedade e da subjetividade do povo brasileiro. São Paulo: Escuta. pp. 81-96.

BENTO, Maria Aparecida da Silva. 2018. "Notas sobre a branquitude nas instituições”. In: Maria Lúcia da Silva et al (orgs.), Violência e sociedade: o racismo como estruturante da sociedade e da subjetividade do povo brasileiro. São Paulo: Escuta. pp. 115-136.

BRAZIL. 1973. "Lei n.o 6.011, de 19 de dezembro de 1973”. Available on http:||www.planalto.gov.br/ccivil_03/ leis/16001.htm Accessed December 20, 2020.

CASTILHO, Ela Wiecko Volkmer de. 2019. "Indígenas na Prisão: o Déficit da Perspectiva Intercultural”. In: Assis da Costa Oliveira et al. (orgs.), Lei do Índio ou Lei do Branco - Quem Decide? Sistemas Jurídicos Indígenas e Intervenções Estatais. Rio de Janeiro: Lumen Juris. pp. 127-156.

. 2021. "Pela descolonização do poder no sistema de justiça: o caso da ocupação da Usina Hidrelétrica de Tucuruí pelo Movimento de Atingidos por Barragens (MAB)”. In: José Geraldo de Sousa Junior (org.), O Direito Achado na Rua: Introdução crítica ao direito como liberdade. Brasilia: OAB Editora/ Editora Universidade de Brasília. pp. 171-187.

CNJ - Conselho Nacional de Justiça. 2018. "Perfil Sociodemográfico dos Magistrados”. Available on: https:/| www.cnj.jus.br/wp-content/uploads/2011/02/5d6083ecf7b311a56eb12a6dgb79c625.pdf Accessed on December 10, 2020. 
. 2019. "Manual Resolução 287/2019: Procedimentos relativos a pessoas indígenas acusadas, rés, condenadas ou privadas de liberdade. Orientações a Tribunais e Magistrados para cumprimento da Resolução 287/2019 do Conselho Nacional de Justiça”. Available on https:/|www.cnj.jus.br/wp-content/ uploads/2019/og/Manual-Resolu\%C3\%A7\%C3\%A30-287-2019-CNJ.pdf Accessed on December 10, 2020. . 2020a. "Recomendação no 62, de 17 de março de 2020: Recomenda aos Tribunais e magistrados a adoção de medidas preventivas à propagação da infecção pelo novo coronavírus - Covid-19 no âmbito dos sistemas de justiça penal e socioeducativo". Available on https:/www.cnj.jus.br/wp-content/ uploads/2020/03/62-Recomenda\% $\mathrm{C}_{3} \% \mathrm{~A} 7 \% \mathrm{C}_{3} \% \mathrm{~A}_{30}$.pdf Accessed on December 10, 2020. . 2020b. "Portaria no 190, de 17 de setembro de 2020. Institui o Grupo de Trabalho denominado 'Observatório dos Direitos Humanos do Poder Judiciário’ e dá outras providências”. Available on: https:|| atos.cnj.jus.br/atos/detalhar/3483 Accessed on December 10, 2020.

. 2020c. Banco Nacional de Monitoramento de Prisões 2.o. Avaiable in https:||portalbnmp.cnj.jus.br|\#| estatisticas. Accessed on December 10, 2020.

CORDEIRO, Ana Clara Monteiro et al. 2020. "Aplicabilidade do regime de semiliberdade e o direito dos povos indígenas no Brasil”. IX Seminário Regional de Extensão Universitária da Região Centro-Oeste, Cuiabá, 4/9/2020. Mimeo.

CORR, J. 2014. "The Enlightenment Surfaces in Nineteenth-Century Mexico: Scientific Thinking Attempts to Deliver Order and Progress". History of Science, [s. 1.], 52(1): 98-123.

FLORES, Joaquín Herrera. 2008. "La complejidad de los derechos humanos. Bases teóricas para una redefinición contextualizada". Revista Internacional de Direito e Cidadania, 1(1): 103-136.

GÓES, Weber Lopes. 2018. "Formação social do Brasil e a objetivação do racismo no pensamento conservador”. In: Maria Lúcia da Silva et al. (orgs.), Violência e sociedade: o racismo como estruturante da sociedade e da subjetividade do povo brasileiro. São Paulo: Escuta. pp. 97-113.

HILGERT, Caroline Dias et al. 2020. Cartilha em Quadrinhos para Pessoas Indígenas Presas e suas Comunidades.

São Paulo: Associação Juízes para a Democracia, Conselho Indigenista Missionário, Instituto Brasileiro de Ciências Criminais, Instituto das Irmãs da Santa Cruz, Instituto Terra Trabalho e Cidadania.

Available on https://www.ibccrim.org.br/media/posts/arquivos/arquivo-16-07-2020-14-26-16-637806.pdf Accessed December 20.2020.

HUNGRIA, Nélson. 1958. Comentários ao Código Penal. Vol. I, Tomo 2o (Arts. 11 a 27). Rio de Janeiro: Revista Forense.

ILO - International Labour Organization. 1989. “C169 - Indigenous and Tribal Peoples Convention No. 169". Available on https:/|www.ilo.org/dyn/normlex/en/f ?p=NORMLEXPUB:12100:0::NO::P12100_ILO_ CODE:C169 Accessed on December 20.2020.

JEFFRIES, S.; STENNING, P. 2014. "Sentencing Aboriginal Offenders: Law, Policy, and Practice in Three Countries". Canadian Journal of Criminology and Criminal Justice, 56(4): 447-494.

LEÃO, Laurindo. 1913. "A questão da responsabilidade". Revista acadêmica da Faculdade de Direito do Recife, 21: 3-138. Available on https://periodicos.ufpe.br/revistas/ACADEMICA/issue/view/2835/showToc Accessed on January 24.2022.

MJSP - Ministério da Justiça e da Segurança Pública. 2019. Departamento Penitenciário Nacional. 2019.

"Nota Técnica no 53/DIAMGE/CGCAP/DIRPP/DEPEN/MJ, com objetivo de recomendar aos órgãos estaduais de administração penitenciária a adoção de medidas necessárias e efetivas à custódia das pessoas indígenas privadas de liberdade nos estabelecimentos penais, atendendo aos regramentos internacionais e nacionais". Processo no 08016.012501/2018-17, de 6/6/2019. Available on https:/|www. mprs.mp.br/normascovid19/ministerios-covid/ Accessed on December 10.2020. 
. 2020a. "Nota Técnica no 77/DIAMGE/CGCAP/DIRPP/DEPEN/MJ: apresenta dados de indígenas que se encontram no sistema prisional brasileiro, com intuito de mapear as etnias que possuem membros em situação de prisão. Processo no 08016.018784/2018-01 de 25/5/2020". Available on http://antigo.depen.gov. br/DEPEN/copy_of_SEI_MJ11751702NotaTcnicaLevantamentoIndigena.pdf Accessed on December 10, 2020.

. 2020b. "Levantamento Nacional de Informações Penitenciárias - INFOPEN 2020.

Painel interativo de julho a dezembro de 2019". Available on https:/|app.powerbi.com/ view?r=eyJrIjoiZTlkZGJjODQtNmJlMiooOTJhLWFlMDktNzRlNmFkNTMoMWI3liwidC I6ImViMDkwNDIwLTQoNGMtNDNmNyo5MWYyLTRiOGRhNmJmZThlMSJg Accessed on December 10, 2020.

OAS - Organization of American States. 2016. "American Declaration on the Rights of Indigenous Peoples." Available on https://www.oas.org/en/sare/documents/DecAmIND.pdf Accessed on December 10.2020.

OSÓRIO, Daniele de Souza. 2020. "A pena de prisão no Brasil: o encarceramento de indígenas em Mato Grosso do Sul - multiculturalismo e o direito à identidade”. In: Luiz Henrique Eloy Amado (org.), Justiça Criminal e Povos Indígenas no Brasil. São Leopoldo: Karywa. pp. 28-46.

PASTANA, Débora Regina. 2012. "Estado punitivo brasileiro na perspectiva da criminologia crítica”. In: Paulo César Corrêa Borges (org.), Leituras de um realismo jurídico-penal marginal: homenagem a Alessandro Baratta. São Paulo: NETPDH, Cultura Acadêmica Editora. pp. 175-198.

QUIJANO, Aníbal. 200o. "Colonialidad del poder y clasificación social”. Journal of world-systems research, $6(2): 342-386$.

RODRIGUES, Nina. 1894. As raças humanas e a responsabilidade penal no Brazil: com um estudo do Professor Afrânio Peixoto. Rio de Janeiro: Editora Guanabara.

SANTELLI, I. H. S.; BRITO, A. G. 2014. "Da sociologia do desvio à criminologia crítica: os indígenas de Mato Grosso do Sul como outsiders". Ciências Sociais Unisinos, 50(1): 65-76.

SILVA, Cristhian Teófilo da. 2009. "Criminalização indífena e abandono legal: aspectos da situação penal dos índios no Brasil” In: Cristhian Teófilo da Silva et al. (orgs.), Problemáticas sociais para sociedades plurais: políticas indigenistas, sociais e de desenvolvimento em perspectiva comparada. São Paulo: Annablume/ Distrito Federal: FAP-DF. pp. 209-222.

SILVA, Tédney Moreira da. 2015. No banco dos réus, um índio: criminalização de indígenas no Brasil. Dissertação de Mestrado, Universidade de Brasília, Brasília. Available on https:||repositorio.unb.br| handle/10482/18728. Accessed on December 10, 2020.

SINGH, D. et al. 2019. "Overincarceration of Indigenous people: a health crisis". CMAJ : Canadian Medical Association Journal, Journal de l'Association Medicale Canadienne, 191(18): E487-E488.

STF - Supremo Tribunal Federal. 2020a. "Ação de Descumprimento de Preceito Fundamental no 684/DF, proposta pelo Partido Socialismo e Liberdade - PSOL”. Available on http:||portal.stf.jus.br/processos/ detalhe.asp?incidente=5910249 Accessed on December 10, 2020.

. 2020b. "Ação de Descumprimento de Preceito Fundamental no 709/DF, proposta pela Articulação dos Povos Indígenas do Brasil - APIB”. Available on http://portal.stf.jus.br/processos/detalhe. asp?incidente $=5952986$ Accessed on December 10, 2020. . 2020c. "Habeas Corpus 183.598/MS". Available on https://redir.stf.jus.br/paginadorpub/paginador. jsp?docTP=TP\&docID=755391604 Accessed on December 10, 2020.

STJ - Superior Tribunal de Justiça. 2019. "Recurso em Habeas Corpus n.o 113.309-BA (2019/0149496-6). Available on https://processo.stj.jus.br/processo/dj/documento/mediado/?tipo_documento=documento \&componente=MON\&sequencial $=117084934 \&$ tipo_documento=documento\&num_registro $=20190149496$ $6 \&$ data $=20201027 \&$ tipo=0\&formato=PDF Accessed on December 10, 2020. 
VALVERDE, Ricardo. 2020. "Relatório avalia disseminação da Covid-19 entre indígenas". Available on https:|| portal.fiocruz.br/noticia/relatorio-avalia-disseminacao-da-covid-19-entre-indigenas. Accessed on January 2, 2021.

WEATHERBURN, D.; FINSDLAY, M. 1985. "Positivism, empiricism and criminological theory". Legal Studies, 5: 191-204.

UN - United Nations. 2007. "United Nations Declaration on the Rights of Indigenous Peoples". Available on https:/www.un.org/development/desa/indigenouspeoples/declaration-on-the-rights-of-indigenouspeoples.html Accessed on December 10, 2020.

YU, A. 2019. "Direct Discrimination and Indirect Discrimination: A Distinction with a Difference". Western Journal of Legal Studies, 9(2): 1-21.

Ela Wiecko Volkmer de Castilho

University of Brasília - Law College

https://orcid.org/oooo-0001-7215-5755

Author's corresponding address: elawiecko@gmail.com

Tédney Moreira da Silva

University of Brasília - Law College

https://orcid.org/0000-0001-5285-5981

Author's corresponding address: tedney.silva@gmail.com 